International Journal of Engineering \& Technology, $9(4)(2020) 842-849$
International Journal of Engineering \& Technology
SPC
Website: www.sciencepubco.com/index.php/IJET
Research paper

\title{
Rheological properties measurement of Mucuna solannie as cement slurry extender: characterization and verification using rheological models
}

\author{
Igwilo K. Chinwuba ${ }^{1}$, UwaezuokeNnaemeka ${ }^{1 *}$, Onyebuchi Nwanwe' ${ }^{1}$ Amaefule C. Vivian ${ }^{2}$, Abubakar U. Raji $^{3}$ \\ ${ }^{1}$ Department of Petroleum Engineering, Federal University of Technology, Owerri, Imo State, Nigeria \\ ${ }^{2}$ Madonna University, Nigeria \\ ${ }^{3}$ Baze University, Nigeria \\ *Corresponding author E-mail:nnaemeka.uwaezuoke@futo.edu.ng
}

\begin{abstract}
Rheological properties of lead cement slurry with Mucuna solannie admixture as an extender was measured in accordance with API standard. Bentonite extender was used as a control. The elemental and oxide compositions of Mucuna solannie were determined using Scanning Electron Microscope and X-Ray Florescence (XRF) methods, and rheological properties were obtained using rheometer after conditioning. The rheological data from Mucuna solannie and bentonite lead slurries were validated using Bingham Plastic and HerschelBulkley models. The result showed that Mucuna solannie contains high carbon atomic concentration and is responsible for its high rheological properties values. Lead slurry prepared with Mucuna solannie gave higher plastic viscosity, yield point and gel strength than that of bentonite. Herschel-Bulkley model described the rheological properties better than Bingham Plastic model. Due to high rheological properties values of the slurry prepared with Mucuna solannie, dispersant is needed for the optimization of the yield point and gel strength.
\end{abstract}

Keywords: Bentonite; Elemental Composition; Lead Slurry; Mucuna solannie; Oxide Composition; Rheological Properties.

\section{Introduction}

The rheology of conventional cement paste is not as complicated as that of cement slurries used in oil well operations. Rapid gel formation, collapse under stress which depends on inter-particle forces, and destruction of gel fragments are elementary factors that describe cement slurry rheology [1]. Also, with particle size distribution (PSD) analysis, another work modified Krieger - Dougherty model, and showcased particle diameter, surfactants and clusters effects on effective viscosity of nanofluids [2]. Similarly, other researchers investigated the effects of temperature on water-based mud properties like Mucuna solannie mud and Detarium microcarpum, Brachystegea eurycoma, Pleurotus mud [3], [4]. They discovered that rheological properties decreased with temperature increase, and fluid loss increased with temperature increase. Both drilling mud and cement slurry are all pseudo-plastic fluids; they have similar behavior in terms of rheological properties because they are all pseudo plastic fluids. Also, another researcher investigated chemical admixtures effects on rheology mechanisms in oil/water cement slurries at varying temperatures where advanced shear-strain/shear-stress rheometer was applied [5]. Cement paste morphology and hydrated products phase compositions were studied with Scanning Electron Microscope and Xray diffraction analysis. As admixtures dosage increased, adsorption on cement particles increased and cements particles negative charge increased. The result was greater repulsion which enhanced the cement paste rheological properties [6]. Rheological properties optimization, such as plastic viscosity and yield stress, can be achieved with statistical design if cementitious materials supplements are applied at varying temperatures. Also, it could be used to better understand the trade-offs with key mixtures parameters, such as superplasticizer's dosage, and supplementary cementitious materials level [7]. It was presented that rheological properties of oil/water cement slurries depend highly on additive used, water/cement ratio and temperature. Rheological behavior of cement is important for the drilling process; it will be optimum to predict correctly about slurry placement. Controlling the rheological behavior of cement slurries can help to improve the relevant movement between particles, the stability and substitutability according to the API standard [8]. A study of oil well cement slurries rheological behavior presented that inter-particle attraction is suppressed by dispersant molecules by cement particles' surface saturation which results in sedimentation [9].

Also, experiments have been carried out on the use of ilmenite plant dusts as substitutes to barite as densifier in cement slurries. Rheological investigation showed that proper dispersion could guarantee application of one of the ilmenites [10]. Various admixtures usually added to cement slurries always depend on purpose of the cementing hole conditions for a successful cementing operation. The process suggested that low-shear-rate dynamic viscosity would govern sedimentation. Using different additives during the formulation of cement slurry gives has economic advantage and environmental benefits. Hardened cementations matrix quality and end-use performance predic- 
tion, combined with physical properties when processed are determined by rheological properties. Laboratory measurement of cementbased materials rheology is still a challenge. However, Newtonian model and non-Newtonian model are used to describe rheology. The orientation or distortion of particles that oppose Brownian motion effects, caused by shear stress transmission are attributable to nonNewtonian flow behavior [2].

In summary, optimization of the rheological behavior of oil well cement slurry should be achieved for optimized cementing. Unfriendly environments necessitate having good durability and mechanical properties in the well life cycle. A material could exhibit yield stress based on test conditions. It has been shown that geometry affects yield stress of cement pastes [11]. Viscosity of a sample varies since shear rate is the determining factor Thus, apparent viscosity is used for any shear rate specified. Bingham Plastic and Herschel-Bulkley models are the two rheological models applied in this research where cement slurry was prepared with Mucuna solannie as extender, while cement slurry prepared with bentonite on equal concentration was used as a control.

\subsection{Characterization of Mucuna solannie}

Mucuna is found worldwide both in Africa and Asia; they are leguminous and are used for culinary purposes [12, 13]. Its use in industrial sector for rheology control has been tested. Mucuna solannie can be used as a cash crop. Planting of the seed in square pattern, with 10,000 plants every hectare, can yield 63.6 metric tons in a year if no filler crops are planted, and a plant for every hill is used [14]. That was proposed to ascertain that the crop would be available when required in oil and gas drilling activities.

\section{Materials and method}

The elemental and oxide compositions measurement of Mucuna solannie were carried out, followed by slurry rheological properties laboratory measurements prepared using Mucuna solannie as an extender and bentonite as a control.

This section is divided into 6 parts, namely; (a) Collection of the Mucuna solannie (b) Physical pre-treatment and processing of the Mucuna solannie (c) Elemental and Oxide compositions measurements (d) Cement slurry formulation (e) Conditioning of cement slurry (f) Cement slurry rheological properties measurement. These measurements were carried out in accordance with API [15].

\subsection{List of apparatus/materials}

Apparatus and materials used were X-Ray Fluorescence (XRF) Cu-Zn, Scanning Electron Microscope, electronic weighing device, variable speed mixer, variable speed viscometer, measuring cylinders, spatula, stop watch, bentonite, Mucuna solannie, Class G cement, defoamer and fresh water.

\subsection{Collection of Mucuna solannie}

The Mucuna solannie utilized for this study were obtained from Ogbaete Enugu market, Enugu state of Nigeria.

\subsection{Processing of Mucuna solannie}

The sorted seeds were cracked open with a sledge hammer to allow for water to seep into the seed. The water helps in softening the seed and allow for easy removal from the seed coat. For the optimization of carbohydrate, the seeds were boiled, allowed to cool, and thereafter dried in a moisture extractor oven at $149^{\circ} \mathrm{F}$. The dried seeds were ground. The flour was screened through a standard test BS sieve $(0.63 \mathrm{~mm})$ to obtain flour particle size.

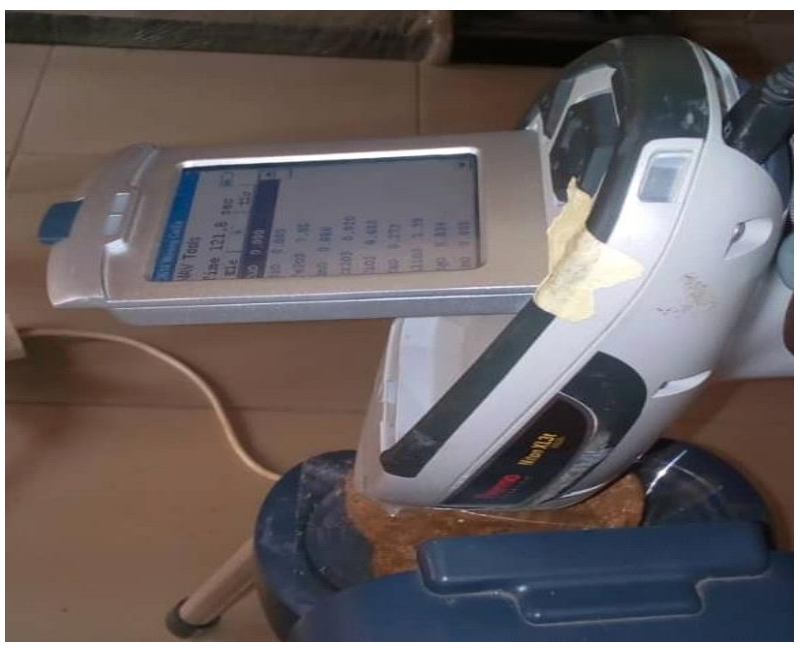

Fig. 1: Scanning Electron Microscope (SEM).

\subsection{Elemental composition measurement using SEM/EDS method}

The Scanning Electron Microscope - Energy Dispersion Spectroscopy (SEM) Phenom Prox (by Phenom World Eindhoven) was used to carry out the morphology and elemental analyses. With a sticky carbon tape, sample was placed in the Aluminium stub. The sample was insulated using gold and then grounded electrically. Each sample was then labeled on their stub, and then dried in the oven at $140^{\circ} \mathrm{F}$ for 3 hours. Nitrogen line was opened at $50 \mathrm{psi}$ and the vent button was pressed to fill the area with nitrogen for proper purging of the chamber. The sample holder stub was then placed in the sample chamber holes, the door was shut and rotary pump picked. At about 35 minutes, vacuum of $5 \times 10^{-5} \mathrm{~Pa}$ was created. The filament light was switched on and the monitor automatically switched on. At this stage, 
the peak accelerator voltage read $15 \mathrm{kV}$ and the filament burned out. Specific wavelengths of X-rays are emitted when electron beams excite surface atoms which characterize the elements atomic structures. Dispersive energy detector analyzes the emissions, assigning elements, which yields atomic composition. The lowest scan mode of 10x was picked and the TV scan clicked. The magnification was then taken to $1000 \mathrm{x}$ at a slow scan, 2000, 3000 to 10,000. Image was then saved. This is known as energy dispersive X-ray spectroscopy (EDS), and it is used for specimen surface composition analyses, with diagram shown in Figure 1, and results in Figures 2 to 4 . The elemental and oxide compositions determined using X-Ray Fluorescence (XRF) $\mathrm{Cu}-\mathrm{Zn}$ is in Tables 5 and 6.

\subsection{Cement slurry formulation}

Two formulations were carried out using Mucuna solannie and Bentonite extender additives, conditioned at both bottom hole circulating temperature of $200^{\circ} \mathrm{F}$ and $150^{\circ} \mathrm{F}$ respectively as shown from Table 1 to Table 4 .

Table 1:Bentonite Extender Slurry Composition

\begin{tabular}{ll}
\hline Slurry name & Lead slurry \\
\hline Cement sack weight & $94.0 \mathrm{lb} / \mathrm{sk}$ \\
Slurry density & $12.0 \mathrm{lb} / \mathrm{gal}$ \\
Slurry yield & $2.397 \mathrm{ft} / \mathrm{sk}$ \\
Cement type & Conventional cement \\
Mix water type & Fresh water \\
Mix water required & $14.175 \mathrm{gal} / \mathrm{sk}$ \\
Mix fluid required & $14.334 \mathrm{gal} / \mathrm{sk}$ \\
Slurry composition & Class G cement +0.0313 -gal ASP- $-742+3 \%$ BWOC Bentonite \\
\hline
\end{tabular}

Slurry composition

Table 2:Bentonite Extender Slurry Formulation

\begin{tabular}{|c|c|c|c|c|}
\hline Additives & Function & Concentration & Weight (gram) & Volume $(\mathrm{ml})$ \\
\hline Class $\mathrm{G}$ cement & Cement & $100 \% \mathrm{BVOB}$ & 377.66 & 120.27 \\
\hline ASP-742 & Defoamer & $0.0313 \mathrm{gal} / \mathrm{sk}$ & 0.95 & 1.05 \\
\hline Bentonite & Extender & $3 \%$ BWOC & 11.33 & 4.28 \\
\hline Fresh water & Mix water & $14.175 \mathrm{gal} / \mathrm{sk}$ & 474.40 & 474.40 \\
\hline Total & & & 864.35 & 600.00 \\
\hline Mix fluid & & $14.334 \mathrm{gal} / \mathrm{sk}$ & 486.35 & 479.79 \\
\hline
\end{tabular}

Table 3: Mucuna solannie Extender Slurry Composition

\begin{tabular}{ll}
\hline Slurry name & Lead slurry \\
\hline Cement sack weight & $94.0 \mathrm{lb} / \mathrm{sk}$ \\
Slurry density & $12.01 \mathrm{~b} / \mathrm{gal}$ \\
Slurry yield & $2.357 \mathrm{ft}^{3} / \mathrm{sk}$ \\
Cement type & Conventional cement \\
Mix water type & Fresh water \\
Mix water required & $13.741 \mathrm{gal} / \mathrm{sk}$ \\
Mix fluid required & $14.033 \mathrm{gal} / \mathrm{sk}$ \\
Slurry composition & Class G cement $+0.0313 \mathrm{gal} / \mathrm{sk}$ ASP-742 $+3 \%$ BWOC Mucuna solannie \\
\hline
\end{tabular}

Table 4: Mucuna solannie Extender Slurry Formulation

\begin{tabular}{|c|c|c|c|c|}
\hline Additives & Function & Concentration & Weight (gram) & Volume (ml) \\
\hline Dyckerhoff G cement & Cement & $100 \% \mathrm{BVOB}$ & 384.11 & 122.23 \\
\hline ASP-742 & Defoamer & $0.0313 \mathrm{gal} / \mathrm{sk}$ & 0.97 & 1.07 \\
\hline Mucuna solannie & Extender & $3 \%$ BWOC & 11.52 & 8.86 \\
\hline Fresh water & Mix water & $13.741 \mathrm{gal} / \mathrm{sk}$ & 467.74 & 467.74 \\
\hline Total & & & 864.35 & 600.00 \\
\hline Mix fluid & & $14.033 \mathrm{gal} / \mathrm{sk}$ & 480.23 & 477.65 \\
\hline
\end{tabular}

\subsection{Atmospheric pressure conditioning}

The formulated cement lead slurry using Bentonite and Mucuna solannie was respectively conditioned at $\mathrm{BHCT}$ of $150^{\circ} \mathrm{F}$ and $200^{\circ} \mathrm{F}$ in accordance with API procedure.

Within 1 minute after mixing, the slurry container of the atmospheric pressure consistometer was filled to the marked line. The test fluid was heated from ambient temperature to the desired temperature. The slurry container preheated to the desired temperature was placed in the atmospheric consistometer cell. After the slurry reached test temperature, the test temperature was held for $+/-30$ minutes to allow the test fluid temperature to reach equilibrium. The paddle was removed and the test was stirred briskly with a spatula to ensure consistency.

\subsection{Rheological properties and gel strength measurements}

The conditioned test slurry extended with Bentonite and Mucuna solannie was respectively poured into the preheated viscometer cup to a level adequate to raise the fluid to the scribed mark on the rotor without the rotor or bob touching the bottom of the cup. The initial dial reading was taken after 10 seconds of continuous rotation at 3 RPM. The remaining dial readings at other speeds were taken, first at ascending order and then in descending order. The highest speed used was 300 RPM. The ratio of the dial readings was also taken during ramp up to ramp down at each speed. The ratio was used to qualify the fluid properties as shown in Table 8 in the attachment.

\section{Results}

\subsection{Results presentation}


These include the results obtained from the determination of the elemental and oxide compositions using both X-Ray Fluorescence (XRF) $\mathrm{Cu}-\mathrm{Zn}$ and SEM methods as shown in Tables 5, 6, 7 and Figures 2 and 3 of plot view runs and SEM map.

Table 5:Elemental Composition of Sample Using X-Ray Fluorescence (XRF) Cu-Zn Method

\begin{tabular}{|c|c|c|c|}
\hline Element & Run 1 & Run 2 & Run 3 \\
\hline $\mathrm{Mg}$ & $<\mathrm{LOD}$ & $<\mathrm{LOD}$ & $<\mathrm{LOD}$ \\
\hline $\mathrm{Al}$ & 0.985 & 0.967 & 0.937 \\
\hline Bal & 95.746 & 94.126 & 95.073 \\
\hline $\mathrm{Si}$ & 2.564 & 2.251 & 2.771 \\
\hline$P$ & 0.314 & 0.318 & 0.312 \\
\hline S & 0.281 & 0.279 & 0.280 \\
\hline $\mathrm{Cl}$ & 0.012 & 0.013 & 0.013 \\
\hline K & 1.449 & 1.455 & 0.454 \\
\hline $\mathrm{Ca}$ & 0.414 & 0.416 & 0.397 \\
\hline $\mathrm{Ti}$ & 0.018 & 0.018 & 0.017 \\
\hline V & $<$ LOD & $<\mathrm{LOD}$ & $<$ LOD \\
\hline $\mathrm{Cr}$ & $<\mathrm{LOD}$ & $<\mathrm{LOD}$ & $<\mathrm{LOD}$ \\
\hline $\mathrm{Mn}$ & $<\mathrm{LOD}$ & $<$ LOD & $<$ LOD \\
\hline $\mathrm{Fe}$ & $<\mathrm{LOD}$ & $<\mathrm{LOD}$ & $<$ LOD \\
\hline Co & $<$ LOD & $<$ LOD & $<$ LOD \\
\hline $\mathrm{Ni}$ & $<\mathrm{LOD}$ & $<\mathrm{LOD}$ & $<\mathrm{LOD}$ \\
\hline $\mathrm{Cu}$ & $<\mathrm{LOD}$ & $<\mathrm{LOD}$ & $<$ LOD \\
\hline $\mathrm{Zn}$ & 0.001 & 0.002 & 0.002 \\
\hline As & $<\mathrm{LOD}$ & $<\mathrm{LOD}$ & $<\mathrm{LOD}$ \\
\hline $\mathrm{Se}$ & $<$ LOD & $<$ LOD & $<\mathrm{LOD}$ \\
\hline $\mathrm{Rb}$ & $<\mathrm{LOD}$ & $<\mathrm{LOD}$ & $<\mathrm{LOD}$ \\
\hline $\mathrm{Sr}$ & $<\mathrm{LOD}$ & $<\mathrm{LOD}$ & $<\mathrm{LOD}$ \\
\hline $\mathrm{Zr}$ & $<\mathrm{LOD}$ & $<\mathrm{LOD}$ & $<$ LOD \\
\hline $\mathrm{Nb}$ & $<$ LOD & $<$ LOD & $<$ LOD \\
\hline Mo & $<\mathrm{LOD}$ & $<\mathrm{LOD}$ & $<\mathrm{LOD}$ \\
\hline $\mathrm{Pd}$ & $<\mathrm{LOD}$ & $<\mathrm{LOD}$ & $<$ LOD \\
\hline $\mathrm{Ag}$ & $<\mathrm{LOD}$ & $<\mathrm{LOD}$ & $<$ LOD \\
\hline $\mathrm{Cd}$ & 0.001 & 0.002 & 0.001 \\
\hline Sn & $<$ LOD & $<$ LOD & $<\mathrm{LOD}$ \\
\hline $\mathrm{Sb}$ & $<\mathrm{LOD}$ & $<\mathrm{LOD}$ & $<\mathrm{LOD}$ \\
\hline $\mathrm{Ba}$ & $<\mathrm{LOD}$ & $<\mathrm{LOD}$ & $<\mathrm{LOD}$ \\
\hline W & $<\mathrm{LOD}$ & $<\mathrm{LOD}$ & $<$ LOD \\
\hline $\mathrm{Au}$ & $<$ LOD & $<$ LOD & $<$ LOD \\
\hline $\mathrm{Pb}$ & $<$ LOD & $<$ LOD & $<\mathrm{LOD}$ \\
\hline $\mathrm{Bi}$ & $<$ LOD & $<$ LOD & $<$ LOD \\
\hline
\end{tabular}

LOD: Low Detection

Table 6:Oxide Composition Result Using X-Ray Fluorescence (XRF) Cu-Zn Method

\begin{tabular}{llll}
\hline Oxide & Run 1 & Run 2 & Run 3 \\
\hline $\mathrm{CuO}$ & 0.01 & 0 & 0 \\
$\mathrm{NiO}$ & 0 & 0 & 0 \\
$\mathrm{Fe}_{2} \mathrm{O}_{3}$ & 0.011 & 0 & 0.103 \\
$\mathrm{MnO}$ & 0.013 & 0 & 0.019 \\
$\mathrm{Cr}_{2} \mathrm{O}_{3}$ & 0 & 0 & 0 \\
$\mathrm{TiO} 2$ & 0.0167 & 0.029 & 0.022 \\
$\mathrm{CaO}$ & 0.608 & 0.583 & 0.518 \\
$\mathrm{Al} \mathrm{O}_{3}$ & 1.991 & 1.828 & 1.908 \\
$\mathrm{MgO}$ & 0 & 0.243 & 0 \\
$\mathrm{ZnO}$ & 0.01 & 0.003 & 0.008 \\
$\mathrm{SiO}_{2}$ & 4.047 & 4.816 & 4.21 \\
\hline
\end{tabular}


(A)

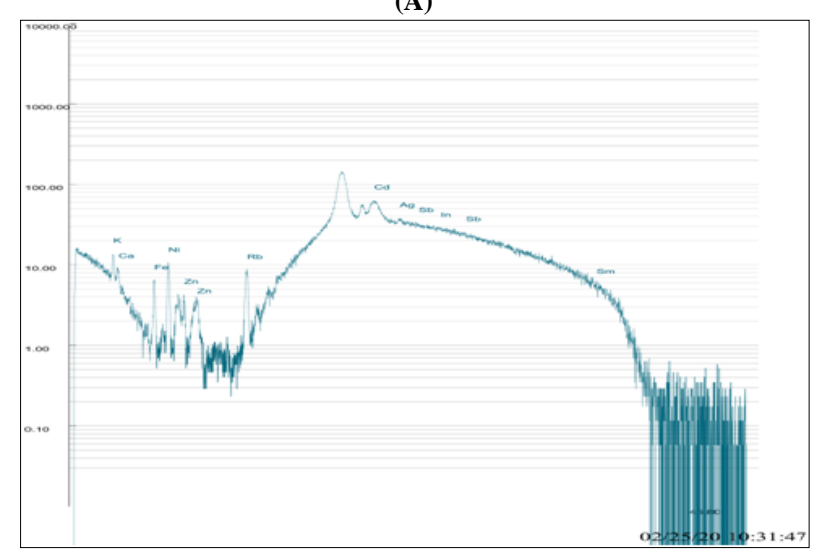

(B)

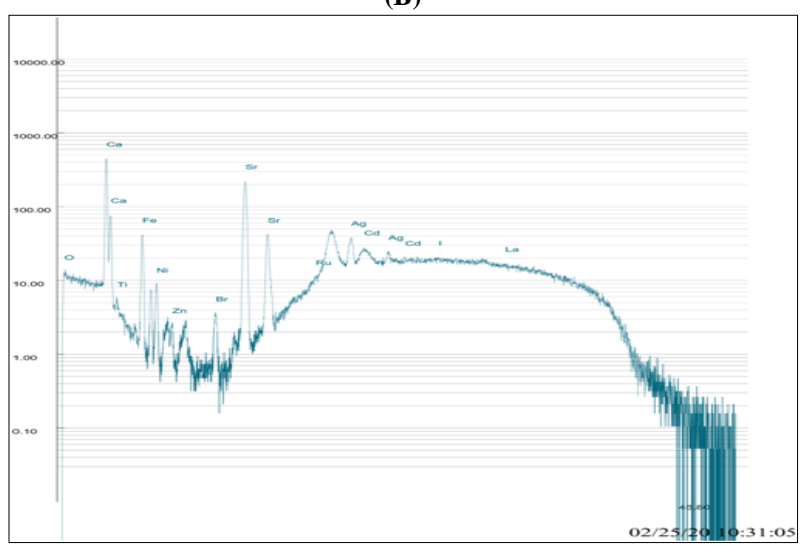

(C)

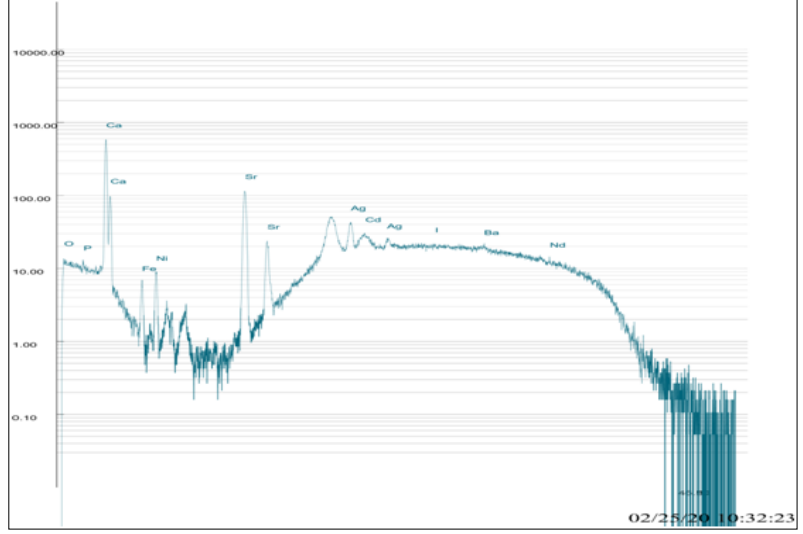

Fig. 2: A, B, C: Plot View of Run 1, Run 2 and Run 3 Using X-Ray Fluorescence (Cu-Zn) Method.

(A)

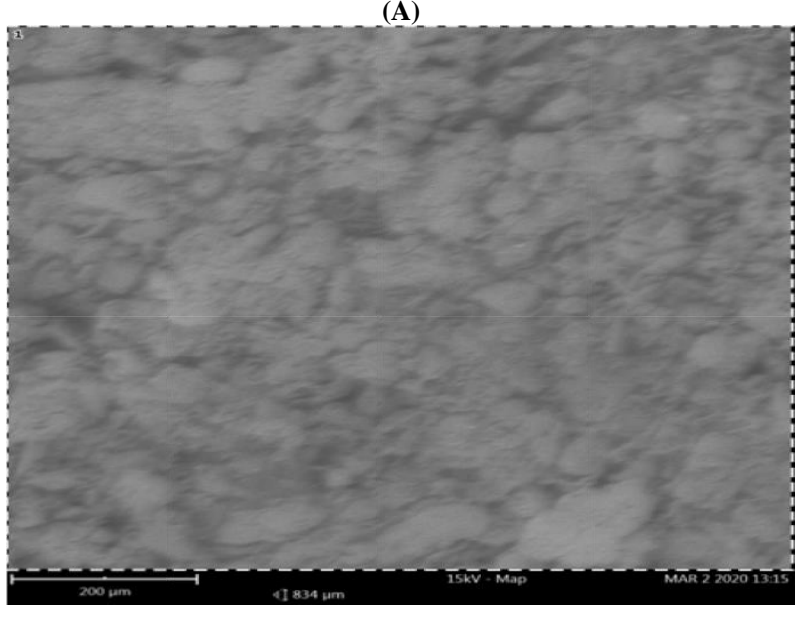

(B)

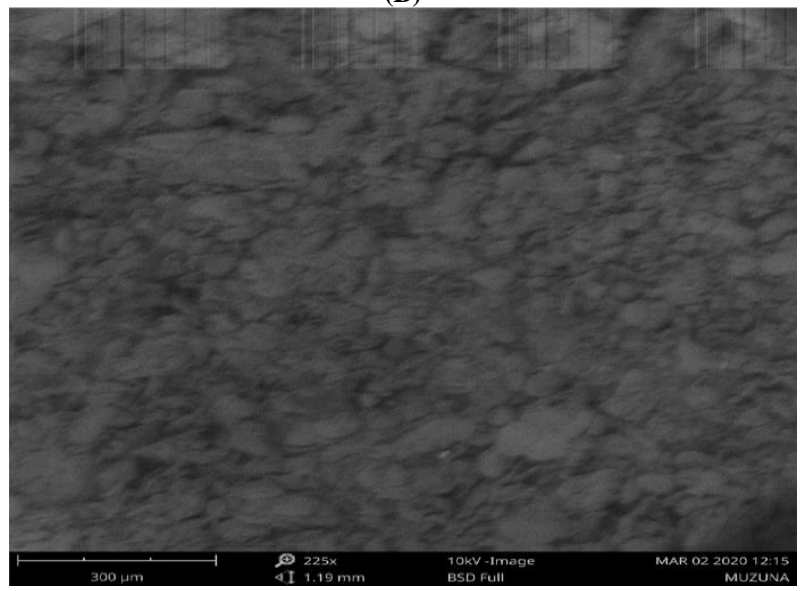

(C)

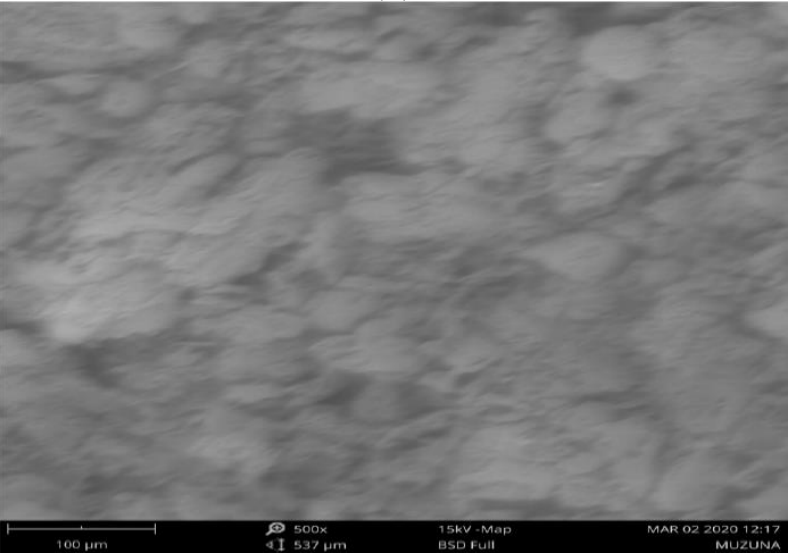

Fig. 3: A, B, C: SEM Map of Mucuna solannie. 


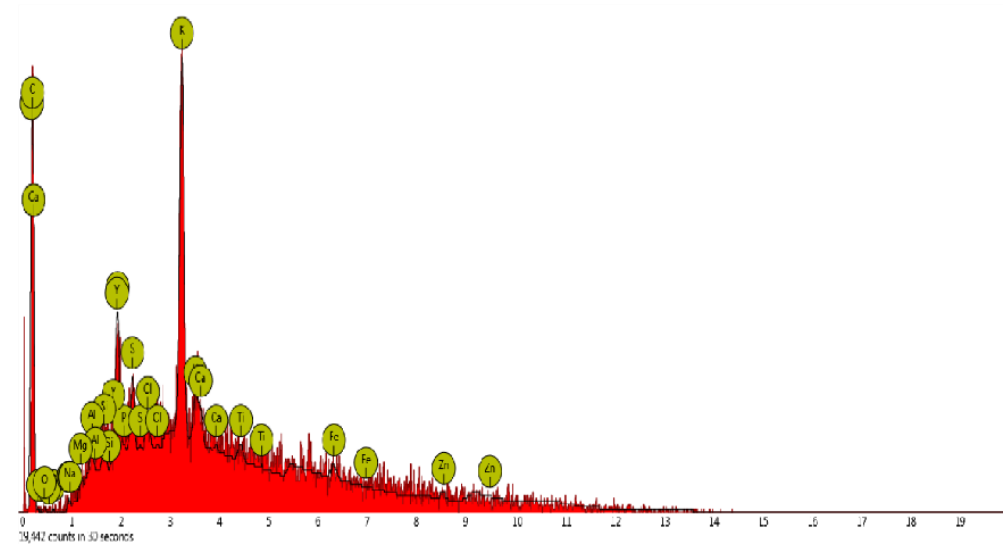

Fig. 4:Plot View of SEM Run Result.

Table 7: Elemental Composition of Mucuna solannie

\begin{tabular}{lllll}
\hline Number & Symbol & Name & Atomic Conc. & Weight Conc. \\
\hline 19 & $\mathrm{~K}$ & Potassium & 28.86 & 39.18 \\
6 & $\mathrm{C}$ & Carbon & 35.27 & 14.71 \\
15 & $\mathrm{P}$ & Phosphorus & 7.34 & 7.89 \\
30 & $\mathrm{Zn}$ & Zinc & 2.81 & 6.37 \\
26 & $\mathrm{Fe}$ & Iron & 2.63 & 5.11 \\
16 & $\mathrm{~S}$ & Sulfur & 4.54 & 5.05 \\
20 & $\mathrm{Ca}$ & Calcium & 3.27 & 4.55 \\
39 & $\mathrm{Y}$ & Yttrium & 1.15 & 3.54 \\
22 & $\mathrm{Ti}$ & Titanium & 1.84 & 3.06 \\
17 & $\mathrm{Cl}$ & Chlorine & 2.19 & 2.70 \\
8 & $\mathrm{O}$ & Oxygen & 3.74 & 2.08 \\
14 & $\mathrm{Si}$ & Silicon & 2.00 & 1.95 \\
13 & $\mathrm{Al}$ & Aluminium & 1.89 & 1.77 \\
12 & $\mathrm{Mg}$ & Magnesium & 1.39 & 1.17 \\
11 & $\mathrm{Na}$ & Sodium & 1.08 & 0.86 \\
\hline
\end{tabular}

Table 8 (Appendix) shows the rheological data obtained from the rheological measurements of the cement slurries prepared with both Mucuna solannie and bentonite respectively as extenders. Their results were then simplified (Table 9).

Table 9: Lead Slurry Rheological Properties Obtained from Mucuna solannie and Bentonite as the Extenders

\begin{tabular}{|c|c|c|c|c|}
\hline Parameters & $\begin{array}{l}\text { Mucuna solannie Design } \\
\text { at } 150^{\circ} \mathrm{F} \text { BHCT }\end{array}$ & $\begin{array}{l}\text { Bentonite Design at } 150^{\circ} \mathrm{F} \\
\text { BHCT }\end{array}$ & $\begin{array}{l}\text { Mucuna solannie Design at } \\
200^{\circ} \mathrm{F} \text { BHCT }\end{array}$ & $\begin{array}{l}\text { Bentonite Design at } 200^{\circ} \mathrm{F} \\
\text { BHCT }\end{array}$ \\
\hline Plastic Viscosity, cP & 89 & 11 & 114 & 8 \\
\hline Yield Point, $\mathrm{lb} / 100 \mathrm{ft}^{2}$ & 67 & 56 & 66 & 46 \\
\hline $10 \mathrm{sec}$. Gel strength, at $77.5^{\circ} \mathrm{F}$ & 13 & 13 & 15 & 10 \\
\hline $10 \mathrm{~min}$. Gel strength, at $150^{\circ} \mathrm{F}$ & 16 & 16 & 22 & 16 \\
\hline
\end{tabular}

\subsection{Results discussion}

The basic reason for determination of rheological properties is to predict plastic viscosity, gel strength and yield point values of the cement slurries in order to qualitatively evaluate the suitability of Mucuna solannie for cementing operations. From Fable 9, it can be seen that cement formulated with bentonite has lower plastic viscosity and also yield point compared to that of the cement formulated with Mucuna solannie. Cement formulated with Mucuna solannie recorded a high plastic viscosity of $89 \mathrm{cP}, 114 \mathrm{cP}$ as compared to $11 \mathrm{cp}, 8 \mathrm{cP}$ for that of Bentonite at $\mathrm{BHCT}$ of $150^{\circ} \mathrm{F}$ and $200^{\circ} \mathrm{F}$ respectively. This showed that lead slurry prepared with Mucuna solannie has more resistance to flow, although it has a better transport capacity than that of lead slurry prepared with bentonite. This shows that it will require a significant amount of dispersant in the lead slurry for mud prepared using Mucuna solannie to work effectively. The high rheological properties values of lead slurry prepared with Mucuna solannie is due to its high carbon atomic concentration obtained from high concentration of carbohydrate as shown in Table 7.

Also, lead slurry prepared with Mucuna solannie gave excessive gel strength and will lead to high pump initiation pressure to break circulation after cement slurry is in a static condition for a period of time. High pump pressure may also result in formation fracture and lost circulation of cement slurry. However, both extenders are suitable for cementing operations due to their appreciable gel strength values obtained, but Mucuna solannie lead slurry has to be dispersed for the good rheological properties to be obtained. 


\subsubsection{Rheological model performance evaluation}

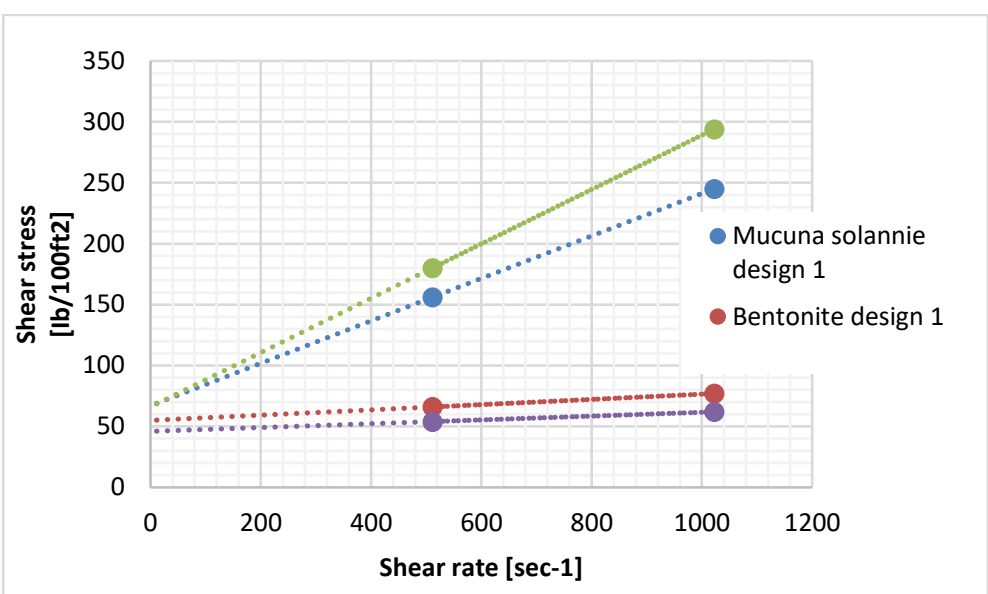

Fig. 5: Mucuna solannie and Bentonite Rheological Plots at $150^{\circ} \mathrm{F}$ and $200^{\circ} \mathrm{F}$ Using Bingham Plastic Model.

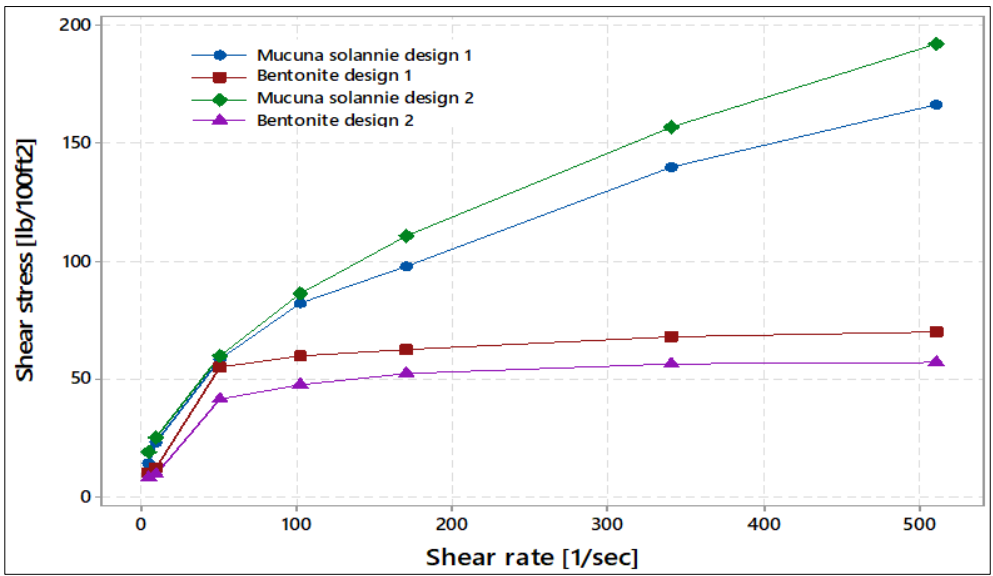

Fig. 6: Mucuna solannie and Bentonite Rheological Plots At $150^{\circ} \mathrm{F}$ and $200^{\circ} \mathrm{F}$ Using Herschel-Bulkley.

Both slurries prepared with Mucuna solannie and Bentonite (Table 8) were evaluated and compared using Bingham Plastic and HerschelBulkley rheological models. Herschel-Bulkley model, using the yield stress, highlighted lead cement slurry of better rheology at both designed BHCT. Herschel-Bulkley model predicts rheology more accurately and characterizes in the entire shear rate range accurately compared to Bingham plastic. Low shear rate yield stress values are indicated, that serve as indicator of annular slurry performance. Compared to Mucuna solannie, bentonite showed greater capacity to be stable at high temperature from the data generated.

\section{Conclusion}

From the performance evaluation, it could be inferred that Mucuna solannie contain high carbohydrate and carbon contents. Lead slurry prepared with Mucuna solannie gave higher rheological results than that of the lead slurry prepared with bentonite extender. Also, dispersant would be needed for enhancement of the rheology of the slurry when using Mucuna solannie as an extender. Herschel-Bulkley model gave a better representation than Bingham plastic model.

\section{Nomenclature/designation}

BWOC = by weight of cement

$\mathrm{BVOB}=$ by volume of blend

BHCT $=$ bottom hole circulating temperature

Design $1=$ experiment at $150^{\circ} \mathrm{F}$

Design $2=$ experiment at $200^{\circ} \mathrm{F}$

\section{References}

[1] Lootens, D., Hebraud, P., Lecolier, E. \& Van Damme, H. (2004). Gelation, shear-thinning and shear-thickening in cement slurries. Oil and gas science and technology 59(1), $31-40$ : https://doi.org/10.2516/ogst:2004004.

[2] Selvakumar, R.D \& Dhinakaran, S. (2017). Effective viscosity of nanofluids - a modified Krieger - Dougherty model based on particle size distribution (PSD) analysis. Journal of molecular liquids, Elsevier, 225: 20-27: https://doi.org/10.1016/j.molliq.2016.10.137.

[3] Uwaezuoke, N., Igwilo, K.C., Onwukwe, S.I. \&Obah, B. (2017). Effects of temperature on Mucuna solannie water-based mud properties. International journal of advanced engineering research and science, 4(1): 83-92: https://doi.org/10.22161/ijaers.4.1.13.

[4] Igwilo, K.C., Osueke, G.C., Okolie, S., Anawe, P.A.L. \&Okoli, N. (2017). Experimental evaluation of temperature effects on Detarium microcarpum, Brachystegea eurycoma and Pleurotus biomaterial mud. Open journal of Yangtze gas and oil, Scientific Research Publishing, 2, 92 - 107: https://doi.org/10.4236/ojogas.2017.22007. 
[5] Shahriar, A. (2011). Investigation of oil well cement slurries, Ph.D. Thesis, University of Western Ontario, School of Graduate and Postdoctoral Studies. Accessed June 8, 2020; 12:39:04 PM: https://ir.lib.uwo.ca/cgi/viewcontent.cgi?article=1231\&context=etd

[6] Habib, A.O., Aiad, I., Youssef, T.A. \& Abd El-Aziz, A.M. (2016). Effect of some chemical admixtures on the physico-chemical and rheological properties of oil well cement pastes. Construction and building materials, 120, 80 -88: https://doi.org/10.1016/j.conbuildmat.2016.05.044.

[7] Shahriar, A. \& Nehdi, M.L. (2012). Optimization of rheological properties of oil well cement slurries using experiment design. Materials and structures, 45(9), 1403 - 1423: https://doi.org/10.1617/s11527-012-9841-2.

[8] Khalil, R.M., Muhannad, T.S., Muhammad, K.M., Arshad, A.L. \& Ghulam, A. (2014). Durability and rheological evaluation of cement slurries from atmospheric to high thermal condition. Journal of applied sciences, 14(11), 1204 - 1209: https://doi.org/10.3923/jas.2014.1204.1209.

[9] Michaux, M. \& Defosse, C. (1986). Oil well cement slurries: microstructural approach of their rheology. Cement and concrete research, ScienceDirect, Elsevier, 16(1), 23 - 30: https://doi.org/10.1016/0008-8846(86)90064-5.

[10] Saasen, A. \& Log, P.A. (1996). The effect of ilmenite plant dust on rheological properties of class G oil well cement slurries. Cement and concrete research, Science direct, Elsevier, 26(5), 707 - 715.https://doi.org/10.1016/S0008-8846(96)85008-3.

[11] Nehdi, M. \& Rahman, M.A. (2004). Estimating rheological properties of cement pastes using various rheological models for different test geometry, gap and surface friction. Cement and concrete research, ScienceDirect, Elsevier, 34(11), 1993 - 2007: https://doi.org/10.1016/j.cemconres.2004.02.020.

[12] Obiakor-Okeke, P.N., Chikwendu J.N. \& Anozie, T. (2014). Effect of different processing methods on the chemical, functional and microbial properties of Mucuna sloanei seeds (Ukpo), International journal of nutrition and food sciences, 3 (6), 551559.https://doi.org/10.11648/j.ijnfs.20140306.20.

[13] Nwosu, J.N. (2012). The rheological and proximate properties of some food thickeners (Ukpo, Achi and Ofo) as affected by processing. International journal of basic and applied Sciences, 1(4), 312-321.

[14] Uwaezuoke, N., Obah, B., Onwukwe, S.I. \& Igwilo, K.C. (2016). An economic evaluation of investment in Mucuna solannie production. International Journal of Environment, Agriculture and Biotechnology (IJEAB), 1(3), 610-620: https://doi.org/10.22161/ijeab/1.3.45.

[15] API RP 10B-2 (2013). Recommended practice for testing well cements. American Petroleum Institute, Second Edition.

\section{Appendix:}

Table 8: Slurry Rheological Properties of Mucuna solannie Extender and Bentonite Extender at 150OF and 200OF BHCT

\begin{tabular}{|c|c|c|c|c|}
\hline \multirow[b]{2}{*}{ Rotational Speed (RPM) } & \multicolumn{2}{|c|}{ Mucuna solannie and Bentonite for 150OF BHCT } & \multicolumn{2}{|c|}{ Mucuna solannie and Bentonite for 200OF BHCT } \\
\hline & $\begin{array}{l}\text { Dial Readings (Mucuna solan- } \\
\text { nie) }\end{array}$ & $\begin{array}{l}\text { Dial Readings (Benton- } \\
\text { ite) }\end{array}$ & $\begin{array}{l}\text { Dial Readings (Mucuna solan- } \\
\text { nie) }\end{array}$ & $\begin{array}{l}\text { Dial Readings (Benton- } \\
\text { ite) }\end{array}$ \\
\hline 3 & 14 & 10 & 18 & 8 \\
\hline 6 & 22 & 12 & 24 & 9 \\
\hline 30 & 55 & 52 & 56 & 39 \\
\hline 60 & 77 & 56 & 81 & 45 \\
\hline 100 & 92 & 59 & 104 & 49 \\
\hline 200 & 131 & 64 & 147 & 53 \\
\hline 300 & 156 & 66 & 180 & 54 \\
\hline 10 sec. gel at $77.6 \mathrm{OF}$ & 13 & 13 & 15 & 10 \\
\hline $10 \mathrm{~min}$. gel at $190 \mathrm{OF}$ & 16 & 16 & 22 & 16 \\
\hline
\end{tabular}

